\title{
ECONOMIC ASPECTS OF LIFELONG LEARNING IN LATVIAN REGIONS
}

\author{
Aija Sannikova \\ Daugavpils Universitāte, Latvia
}

\begin{abstract}
: despite the extreme urgency of lifelong learning in the era of knowledge economy, employers in Latvia's regions are not active investors in the training of their employees, and individuals are not eager to actively educate themselves throughout their lives, mentioning the expensiveness of lifelong learning - unlike in the majority of EU Member States - as the key reason. Therefore, one can identify the discrepancy between the political priorities and the actual situation. The author, following the idea of Latvia's scientist A.Jaunzems to perceive knowledge purely economically - as a product of the education market - developed this idea further by examining the knowledge market in Latvia's regions in regard to its institutional "casing", i.e. lifelong learning. The research findings show that the regional specifics of lifelong learning in Latvia are determined by the fact that Latvia's regions are in different stages of economic development.
\end{abstract}

Key words: lifelong learning, Latvian regions, knowledge market, lifelong learning services and prices, economic development stages.

\section{Introduction}

Lifelong learning has become topical in Latvia and other post-soviet countries since their transition to a market economy in the 1990s when a job was not guaranteed to everyone and the right to be successful had to be "earned". The second "wave" of making lifelong learning urgent in Latvia and other European countries emerged gradually along with great structural changes in the economies of EU countries after the global financial crisis and related structural changes in the labour market in the beginning of the $21^{\text {st }}$ century. In the present situation in the EU and world labour markets, additional competences of an employee - foreign language skills, computer skills, cultural competences and other general and special skills - become the key elements of labour quality, along with the speciality; it makes the employee adapted to the modern labour market requirements.

A few international researches, for instance, a 2010 comparative research on European countries by UNESCO's International Commission on Education for the Twenty-first Century, evidence the overall urgency for lifelong learning in Latvia; the country was ranked in the 18th position among 23 countries in the European Lifelong Learning Index, ELLI (Delors, 1996).

However, comparative studies systematically conducted by Eurostat in all the EU Member States regarding the engagement of individuals aged 25-64 in lifelong learning showed how urgent the economic aspects of lifelong learning were in Latvia (European Commission, 2013). The findings showed that in Latvia, unlike in the EU-27, the engagement of adults in lifelong learning over 
the recent decade followed the economic trends, especially in the crisis period; besides, it was always lower than on average in the EU-27.

The education system, at various its stages, has been researched by economists both in Latvia and abroad, for instance, the commercialisation and globalisation of the education system (Saulītis, Briede, 2006), links between lifelong learning and employment (Sannikova, Baltere, 2008), lifelong learning costs and opportunities for stimulating investment in lifelong learning (McKenzie, 2001; Kokosalakis, 2000; Kokosalakis, Kogan, 2001), the funding system of general education institutions (Eglītis, Jermolajeva, 2007), educational quality assurance from the perspective of regional economy (Eglitis, 2003) and the efficiency of Latvia's higher education system (Panina, 2011).

However, the author believes that professor Andrejs Jaunzems made the greatest contribution to researching the economic aspects of Latvia's education system. He constructed a market model for education in economics and management by using a microeconomic approach, ascertained the behavioural motives of market agents and identified alternatives in Latvia's education market (Jaunzems, 2011, 2013). In his works, A.Jaunzems viewed knowledge purely economically - as a product of the education market -, and the author developed this idea further by examining the knowledge market in Latvia's regions in regard to its institutional "casing", i.e. lifelong learning. For this reason, in the present research, the economic aspects of lifelong learning involve market and institutional aspects.

So, the research problem relates to the fact that despite the extreme urgency of lifelong learning and of knowledge acquired through lifelong learning for all adults in the era of knowledge economy, Latvia's employers are not active investors in the training of their employees, often believing that such investments are quite risky (Millere et al., 2007; Rutkovskis, 2013), and Latvia's individuals are not eager to actively educate themselves throughout their lives, mentioning the expensiveness of lifelong learning - unlike in the majority of EU Member States - as the key reason (Eurostat, 2007). Therefore, one can identify the discrepancy between the political priorities and the actual situation (LR Cabinet of Ministers, 2005, 2006).

The research aim is to examine the characteristics of lifelong learning as an institutionalised knowledge market and the specifics of lifelong learning in Latvia's regions. To achieve the aim, the following methods were employed: the monographic method for the theoretical discussion and for building the methodological basis; analysis and synthesis for the microeconomic modelling of the knowledge market; the graphic method for depicting equilibrium in the knowledge market; the cartographic method for visualising the regional aspects of development of lifelong learning at the level of Latvia's regions; statistical analysis and linear regression for examining empirically the specific economic aspects of lifelong learning in Latvia's regions. 


\section{Research methodology}

While building the methodological basis to examine the economic aspects of lifelong learning in the regions, the author especially focused on whether to take into account, when examining any socio-economic regional aspects, the facts that the regions, being in different stages of economic development, are developed unevenly. Each stage of economic development involves its own driver of growth. Consequently, for instance, the factors of competitiveness in the USA are different from those in Latvia. This aspect was thoroughly examined by the World Economic Forum's global competitiveness reports, classifying regions into five groups corresponding to three main and two transitional stages of economic development (Schwab, 2013):

- the factor-driven stage, in which the key driver of economic development is the intensive use of the factors of production;

- transition from the factor-driven to the efficiency-driven stage;

- the efficiency-driven stage, in which the key driver of economic development is the productivity of resources used in an economy;

- transition from the efficiency-driven to the innovation-driven stage;

- the innovation-driven stage, in which the key driver of economic development is innovations.

The World Economic Forum highlights three basic factors that play a different determinant role in each of the three mentioned basic stages of regional economic development:

- main conditions - institutions, infrastructures, the macroeconomic environment, healthcare and primary education;

- enhancers of efficiency - higher education and training, market efficiency and technological readiness;

- innovations and special factors - business specialisation, innovations.

In the global competitiveness index, the weight of each factor is determined depending on the region's stage of economic development, which means that when calculating a value of the global competitiveness index, each subindex (i.e. the competitiveness factor) is assigned a weight, taking into account the particular region's stage of economic development (Table 1).

As shown in Table 1, in the regions being in the factor-driven stage, the greatest role $(60 \%)$ in economic development is played by main conditions, a significant role is played by enhancers of efficiency (35\%), and only 5\% are assigned to innovations and special factors. For the regions being in the efficiency-driven stage, the role of main conditions decreased to $40 \%$, the role of enhancers of efficiency rose to $50 \%$ and became dominant, even though the roles of innovations and special factors in this stage were relatively low at $10 \%$. Yet, for the regions being in the innovation-driven stage, even though the roles of main conditions and enhancers of efficiency were relatively high, the role of 
innovations and special factors was considerably higher (30\%). The author believes that the knowledge, skills and competences that are "produced" during lifelong learning belong specifically to innovations and special factors, which play the greatest role in a region's economic development when this region is in the innovation-driven stage, and it is not crucial if the region is, for instance, in the factor-driven stage.

Table 1

Weights of various factors for each stage of regional economic development

\begin{tabular}{|l|c|c|c|}
\hline \multicolumn{1}{|c|}{$\begin{array}{c}\text { Stages of economic } \\
\text { development } \\
\text { of regions }\end{array}$} & \multicolumn{3}{|c|}{ Main driver of economic development } \\
\cline { 2 - 4 } & $\begin{array}{c}\text { Main } \\
\text { conditions }\end{array}$ & $\begin{array}{c}\text { Enhancers of } \\
\text { efficiency }\end{array}$ & $\begin{array}{c}\text { Innovations and } \\
\text { special factors }\end{array}$ \\
\hline Factor-driven stage & $60 \%$ & $35 \%$ & $5 \%$ \\
\hline $\begin{array}{l}\text { Pāreja no factor-driven } \\
\text { stage uz efficiency-driven } \\
\text { stage }\end{array}$ & $40-60 \%$ & $35-50 \%$ & $5-10 \%$ \\
\hline Efficiency-driven stage & $40 \%$ & $50 \%$ & $10 \%$ \\
\hline $\begin{array}{l}\text { Pareja no efficiency-driven } \\
\text { stage uz innovation-driven } \\
\text { stage }\end{array}$ & $20-40 \%$ & $50 \%$ & $10-30 \%$ \\
\hline Innovation-driven stage & $20 \%$ & $50 \%$ & $30 \%$ \\
\hline
\end{tabular}

Avots: Schwab, 2013.

Two approaches or paradigms in regard to knowledge perception exist in parallel in the global arena of science and public management: the approach to knowledge as a market good and the approach to knowledge as a public good (Pring, 1995; Stewart, 1996). Presently, scientists and practitioners have no consensus concerning this problem (Dorothy, 1998). The author suggests that actually there is no contradiction between these two approaches if the "sphere of influence" of various sciences and practices is divided. Activities such as managing the public and making a regional development policy have to be certainly based (at least partially) on access to knowledge as a public good that has to be shared in a just way, and all members of society have to be provided with access to new knowledge and competences. Yet, at the same time, one has to understand and consider the fact that a market economy will not actually stop functioning according to the market laws to which all limited resources are subject, including knowledge, too, (especially in their institutionalised form, i.e. "knowledge with a certificate"). Particularly for this reason, the author believes that from the perspective of economics, knowledge is a market good that simultaneously belongs to two types of knowledge market: a consumer market and the market of production factors/resources. Since knowledge as the consumer market and knowledge as the market of production factors are closely interrelated and affect each other, by stimulating changes both in demand and supply and in market equilibrium, the changes should be analysed using the 
general equilibrium conception (Arrow, Debreu, 1954; McKenzie, 1959; Mandler, 1999; Velupillai, 2006; Mitra-Kahn, 2008).

The author suggests the following definition of lifelong learning, which may be especially useful for economic analyses: lifelong learning is an institutional "casing" for the knowledge market in which the knowledge, skills and competences are purchased and sold as market goods according to all the market laws.

Developing a methodology for examining the economic aspects of lifelong learning in Latvia's regions, the author designed a conceptual algorithm that, step by step, allows examining regional market and institutional aspects of the functioning of lifelong learning in Latvia and may be applied to research economic aspects of lifelong learning elsewhere in Europe. This methodological algorithm is based on the World Economic Forum's classification of the stages of economic development for regions, microeconomic models (graphic modelling of demand and supply, a conception for general market equilibrium) and game theories in economics and consists of five steps: 1) identifying the stages of economic development as economic "background" for the functioning of lifelong learning for the regions researched; 2) analysing the institutional "background" of the knowledge market, i.e. institutes of the system of lifelong learning, in the regions researched; 3) analysing the specifics of the knowledge market - consumer market - in the regions researched (demand and supply, market equilibrium, intermediaries, market price); 4) analysing the specifics of the knowledge market - market of production factors - in the regions researched; 5) examining general equilibrium in the institutionalised knowledge market (lifelong learning) in the regions researched, examining market agents' motives and explaining their behaviour.

\section{Research findings}

The analysis performed showed that in terms of economic development level, Latvia's regions are in unequal positions, and the regions may be classified into three groups:

1) only Riga region is in the innovation-driven stage;

2) the regions of Pieriga and Kurzeme are in transition from the efficiencydriven to the innovation-driven stage;

3) the regions of Zemgale, Vidzeme and Latgale are in the efficiency-driven stage.

The research findings allow asserting that the capability of lifelong learning to considerably affect a region's competitiveness may not be equal in all the regions of Latvia at least because of the fact that the regions are in different stages of economic development. Accordingly, the factor of lifelong learning plays the role of boosting economic development in Riga region (the innovationdriven stage) as well as in the regions of Pieriga and Kurzeme (transition from 
the efficiency-driven to the innovation-driven stage), while in the regions of Zemgale, Vidzeme and Latgale lifelong learning is not crucial to their competitiveness.

An analysis of statistical data and of the knowledge market show that the average demand and supply prices of lifelong learning services in Latvia's regions correspond to their classification by stage of economic development and are determined - among the other factors - by the significance of lifelong learning in each stage of economic development for the region (Table 1). So, the highest prices are observed in the regions being in the innovation-driven stage or in transition to it, i.e. in the regions of Riga, Pieriga and Kurzeme. However, in the regions being in the efficiency-driven stage - in the regions of Vidzeme, Zemgale and Latgale - the prices of knowledge are considerably lower.

A considerable gap between the demand and supply prices exists in the knowledge market among all the regions; besides, in Riga region the average supply price of lifelong learning services is 4.7 times higher than the affordable demand price, in Pieriga region it is 4.4 times, in Kurzeme region -7.2 times, in Vidzeme region - 4.9 times, in Zemgale region - 4.2 times and in Latgale region - 4.3 times (the author's calculations based on LR CSB, 2013a, 2013b as well as the websites of enterprises providing lifelong learning services). In this situation, alternative solutions to how to share this cost among the state, individuals, families, employers and other social groups and to achieve high efficiency of returns have to be sought. The author believes that the alternative solutions involve the use of EU lifelong learning instruments and national and international programmes in the knowledge market in Latvia's regions in regard to lifelong learning. As found in the present research, in Latvia's regions being in the innovation-driven stage or in transition to it - in the regions of Riga, Pieriga and Kurzeme - subsidies of intermediaries are able to support the average supply prices of knowledge at the market equilibrium level (lifelong learning services for a few social groups are fully or partially subsidised), thus allowing a greater number of individuals to engage in lifelong learning activities. However, in those regions of Latvia which are in the efficiency-driven stage - in Vidzeme, Zemgale and Latgale - the supply prices of knowledge will not rise, as lifelong learning plays no crucial role in the region's competitiveness at this stage of economic development. However, the intermediaries working in the regional knowledge market can lower the current average supply prices by means of their subsidies for lifelong learning services and reach equilibrium in the knowledge market, thus allowing as many individuals as possible to engage in lifelong learning activities.

However, an analysis of the specifics of the knowledge market as the market of production factors in Latvia's regions allows the author to assert that the factor of lifelong learning makes an indirect and insignificant effect - through a leading job position - on the size of wages. Another factor that considerably contributes to a high wage is an industry of the economy - the best chance to 
earn a high wage belongs to employees working in the industry of transportation and storage, especially in the public sector. Besides, it depends neither on the particular region nor on the stage of economic development (the author's calculations based on LR CSB, 2013c, 2013d, 2013e):

$$
\mathrm{y}=86.098+1.430 * \mathrm{x}_{1}-0.298 * \mathrm{x}_{2}+0.031 * \mathrm{x}_{3}-0.005 * \mathrm{x}_{4}+0.001 * \mathrm{x}_{5}
$$

where:

$\mathrm{y}$ - average monthly wage of employees,

$\mathrm{x}_{1}$ - legislators, government officials, officials holding a position of manager and managers,

$\mathrm{x}_{2}$ - health and social care,

$\mathrm{x}_{3}$ - transportation and storage,

$\mathrm{x}_{4}$ - performance of administrative and support services,

$\mathrm{x}_{5}$ - public sector.

If functioning in a concerted way, the market of knowledge as goods and the market of knowledge as the market of production factors persistently seek to balance each other in Latvia's regions, and the situation in the former certainly determines the situation in the latter. Inadequate economic returns on the knowledge purchased in the consumer market objectively hinder the engagement of employees in activities of lifelong learning and "pull" down the equilibrium in the market of knowledge as goods. Under such conditions, all agents working in the knowledge market - employers, employees, intermediaries and those making the "rules of game" - have their interests and motives that determine the opportunities for developing lifelong learning in Latvia's regions.

\section{Conclusions}

1. The research was based on an algorithm developed by the author for the knowledge market, which consisted of five steps and aimed to identify the specifics of the knowledge market in Latvia's regions and to empirically prove that these specifics depend on the region's stage of economic development.

2. Only Riga region is steadily positioned in the highest - innovation-driven stage, the regions of Pieriga and Kurzeme are in transition from the efficiency-driven to the innovation-driven stage, while the regions of Vidzeme, Zemgale and Latgale are in the efficiency-driven stage.

3. The capability of lifelong learning to considerably affect a region's competitiveness may not be equal in all the regions of Latvia at least because of the fact that the regions are in different stages of economic development. 
4. Latvia's regions may be classified according to the stage of economic development that determines different economic returns on knowledge and, along with it, different preconditions for development in various regions.

5. An analysis of the institutional "background" of lifelong learning development in Latvia's regions show that a hierarchical system of legal acts and all institutional elements of the lifelong learning system are being developed in Latvia.

6. As regards the regional specifics of this institutionalisation, the author concludes that particularly in this aspect, the regional specifics manifest least, as the institutional resources of lifelong learning and the institutional infrastructure emerge in the entire Latvia. However, the performance of uniform institutional instruments, in practice, is certainly affected by the different economic "background" in Latvia's regions.

7. The research results on the regional specifics of the knowledge market as a consumer market, which functions in Latvia's regions against the diverse economic and single institutional background, showed that the behaviours of both purchasers and sellers of knowledge in regard to lifelong learning in Latvia at least partially correspond to the classification of its regions by stage of economic development.

8. Regardless of the fact that during the crisis the size of the knowledge market in the field of lifelong learning considerably decreased in all the regions of Latvia, yet, the amount of knowledge consumed and the price of it still remained significantly higher in the regions being in the innovationdriven stage or in transition to it, i.e. in the regions of Riga and Pieriga.

9. The supply prices of knowledge regarding lifelong learning in the regions of Riga and Pieriga are considerably higher than in the other regions of Latvia that are in the efficiency-driven stage. Kurzeme region is an exception, as the situation in it regarding the demand for and supply of knowledge in the field of lifelong learning is similar to that in the regions being in the efficiency-driven stage.

10. The EU lifelong learning instruments and national and international programmes allow reaching equilibrium in the market of knowledge as goods by maintaining prices stable in the regions of Riga and Pieriga that are in the innovation-driven stage or in transition to it and by lowering prices on knowledge in the field of lifelong learning to an affordable price in those regions that are in the efficiency-driven stage and where the conditions for developing lifelong learning are objectively poorer.

11. Knowledge resulting from lifelong learning activities (knowledge as goods in the market) generates no adequate economic returns in the market of production factors in Latvia's regions, and it may partially explain the relatively low engagement of individuals in lifelong learning in Latvia. 


\section{References}

1. Arrow, K.J., Debreu, G. (1954). The existence of an equilibrium for a competitive economy. Econometrica, 22(3), 265-290.

2. Delors, J. (1996). Learning: the treasure within. Report to UNESCO of the International Commission on Education for the 21st Century. Paris: UNESCO.

3. Dorothy, L. (1998). Wellsprings of Knowledge. Boston: Harvard Business School Press.

4. Eglīitis, J. (2003). Izglītības kvalitātes nodrošināšanas reǵionālie un ekonomiskie aspekti. Promocijas darbs. Jelgava: LLU.

5. Eglītis, J., Jermolajeva, E. (2007). Vispārējās izglītības finansējums Latvijā - problēmas un perspektīvas. Izglītība zināšanu sabiedrības attīstībai Latvijā, 13(2), 224-236.

6. European Comission. (2013). Lifelong learning statistics. Available: http://epp.eurostat. ec.europa.eu/statistics_explained/index.php/Lifelong_learning_statistics (accessed 24.02.2014).

7. Eurostat. (2007). Obstacles to participation in education and training, 2007. Lifelong learning statistics. Available: http://epp.eurostat.ec.europa.eu/statistics_explained/ index.php/Lifelong_learning_statistics (accessed 24.02.2014).

8. Jaunzems, A. (2011). Ekonomikas un vadzinību izglīîibas Latvijas tirgus mikroekonomiskais modelis. Mevdeckis A. (Sast.) Sabiedrība un kultūra. Rakstu krājums, XIII, 621-642.

9. Jaunzems, A. (2013). Štakelberga-Neša alternatīvas Latvijas izglīîibas tirgū. LZA Vēstis, A, 67(1/2), 23-43.

10. Kokosalakis, N. (2000). Lifelong learning in European universities: a preliminary assessment. European Journal of Education, 35(3), 253-375.

11. Kokosalakis, N., Kogan, M. (2001). Lifelong learning: the implications for universities in the EU. Final Report. Available: http://improving-ser.sti.jrc.it (accessed 24.02.2014).

12. Mandler, M. (1999). Dilemmas in economic theory: persisting foundational problems of microeconomics. Oxford: Oxford University Press.

13. McKenzie, L.W. (1959). On the existence of general equilibrium for a competitive economy. Econometrica, 27(1), 54-71.

14. McKenzie, P. (2001). How to make lifelong learning a reality: implications for the planning of educational provision in Australia. Aspin, D., Chapman, J., Hatton, M., Dordrecht, Y. S. (Eds.) International handbook on lifelong learning. Boston: Kluwer Academic Publishers.

15. Millere, I., Medne, L., Rozenbergs, V. (2007). Ieguldījumu nepieciešamības izvērtējums viesmīlības nozares cilvēkkapitālā. Eiropas Sociālā fonda finansētās aktivitātes ,Atbalsts darba tirgus pētījumu veikšanai" Gala ziņojums. Jelgava: LLU.

16. Mitra-Kahn, B. H. (2008). Debunking the myths of computable general equilibrium models."Schwarz Center for Economic Policy Analysis Working Paper No. 01-2008.

17. Paņina, L. (2011). Latvijas augstākās izglìtības sistēmas efektivitātes izpēte un vidēja terminga attīstības modeļi. Promocijas darbs. Daugavpils: DU.

18. Pring, R.A. (1995). Closing the gap: liberal education and vocational preparation. Hodder\&Stoutgghton.

19. Rutkovskis, E. (2013). Cilvēkresursu kā darbaspēka pieejamības analīze Austrumlatgales darba tirgū sociāli-ekonomiskajā aspektā. Available: http://www.kra.lv/wpcontent/uploads/2013/07/E.Rutkovskis1.pdf (accessed 24.02.2014).

20. Sannikova, A., Baltere, R. (2008). Mūžizglītība un nodarbinātība Latvijā. Latvijas Ekonomists. 8, 26-32. 
21. Saulītis, J., Briede, L. (2006). Izglītības sistēmas komercializācija un globalizācija. Tautsaimniecības un uzņēmējdarbības attīstības problēmas. Starptautiskas konferences zinātniskie raksti. Rīga: RTU, 198-203.

22. Schwab, K. (Ed.) (2013). The Global Competitiveness Report 2013-2014. Geneva: World Economic Forum.

23. Stewart, T.A. (1996). Intellectual Capital: The New Wealth of Organizations. McGrawHill.

24. LR Cabinet of Ministers. (2005). Ilgterminga konceptuālais dokuments „Latvijas izaugsmes modelis: Cilvēks pirmajā vietā’. Rules No. 684, 19.10.

25. LR Cabinet of Ministers. (2006). Nacionālais attīstības plāns 2007.- 2013. Available: http://www.politika.lv/index.php?id=10035 (accessed 24.02.2014).

26. LR CSB. (2013a). Table PIA64_L: Average costs spent by participant on adult education by sex, age, level of education and labour status (in lats). Statistical database. Available: http://www.csb.gov.lv/dati/statistikas-datubazes-28270.html (accessed 24.02.2014).

27. LR CSB. (2013b). Table PCG02. Consumer price changes by commodity groups. Statistical database. Available: http://www.csb.gov.lv/dati/statistikas-datubazes28270.html (accessed 24.02.2014).

28. LR CSB. (2013c). Table DSG11_L: Average monthly gross wages and salaries in statistical regions of Latvia by kind of activity (in lats). Statistical database. Available: http://www.csb.gov.lv/dati/statistikas-datubazes-28270.html (accessed 24.02.2014).

29. LR CSB. (2013d). Table DSG10_L: Average monthly wages and salaries by statistical region of Latvia (in lats). Statistical database. Available: http://www.csb.gov.lv/ dati/statistikas-datubazes-28270.html (accessed 24.02.2014).

30. LR CSB. (2013e). Table DSG14_L: Average gross wages and salaries per month by major occupational groups and form of ownership in statistical regions (in October, in lats), 2004-2005. Statistical database. Available: http://www.csb.gov.lv/dati/statistikasdatubazes-28270.html (accessed 24.02.2014).

31. Velupillai, K. V. (2006) Algorithmic foundations of computable general equilibrium theory. Applied Mathematics and Computation, 179(1), 360-369. 